University of Nebraska - Lincoln

DigitalCommons@University of Nebraska - Lincoln

January 2001

\title{
Economic Education and Government Reform in the Republic of Georgia
}

Craig MacPhee

University of Nebraska-Lincoln, cmacphee1@unl.edu

Follow this and additional works at: https://digitalcommons.unl.edu/econfacpub

Part of the Economics Commons

MacPhee, Craig, "Economic Education and Government Reform in the Republic of Georgia" (2001).

Economics Department Faculty Publications. 22.

https://digitalcommons.unl.edu/econfacpub/22

This Article is brought to you for free and open access by the Economics Department at DigitalCommons@University of Nebraska - Lincoln. It has been accepted for inclusion in Economics Department Faculty Publications by an authorized administrator of DigitalCommons@University of Nebraska - Lincoln. 


\section{Economic Education and Government Reform in the Republic of Georgia}

\section{Craig R. MacPhee}

Abstract: The author describes public education through the media and training for government officials and for journalists undertaken as part of economic reform efforts in the Republic of Georgia of the former Soviet Union. The article concludes with a discussion of the necessary conditions for success of these broad-based educational efforts.

Key words: education, Georgia, reform, teaching, transition JEL codes: A29, P30

The economies of the Soviet Union were sick before the demise of Communism and took a turn for the worse after the USSR split into 15 separate republics. The patients fell into depression accompanied by greater unemployment, inflation, poverty and their complementary social ills. Western advisors prescribed PILLS: privatization, investment, liberalization, legislation (to establish the rule of law), and stabilization. There is controversy, however, over the dosage, which was recently summarized by Stiglitz (1999). Shock therapy requires large doses of PILLS over a short time, and gradualism involves low doses over an extended period. Nevertheless, Western economists generally would agree that PILLS are necessary for the restoration of economic growth and future prosperity.

Unfortunately, the patients do not share the Western doctors' confidence in PILLS. Communist propaganda transmitted through the media and schools glorified the productivity of Soviet workers and factories, the security of life isolated from the West, and the "free" government services including electricity and health care. At the same time, the propagandists criticized capitalism for its high crime rates, monopolistic exploitation, and macroeconomic instability. The propaganda was repeated so often that it took on the status of truth. Contradictions, such as high Western living standards could always be attributed to capitalistic imperialism. Even if the average Soviet citizen did not believe all the propaganda, survival in a Marxist totalitarian regime required adoption of a Soviet mindset. Laws were unnecessary; just follow the orders of those in authority, and if one wanted to benefit from the orders, then do the bosses a favor. Do not make a decision; leave it to the higher authorities. Avoid making recommendations, giving specific answers, and taking responsibility; these actions could lead to

Craig $\boldsymbol{R}$. MacPhee is a professor of economics at the University of Nebraska-Lincoln (e-mail: cmacpheel@unl.edu), former Senior Economic Advisor to the Minister of Finance in the Government of Georgia, and Chief Economist, Institutional Reform and the Informal Sector Caucasus Center, Tbilisi. Marah Ovakimian deserves credit for superb translation. 
Siberia or worse. Better to do nothing, to act like everyone else, and to speak with vagueness and ambiguity. There were no private property rights, so you helped yourself to public property. Successful party officials advanced with big new construction projects; never mind the operation, maintenance, and repair of the existing capital stock.

Because production goals were usually quantitative, no one bothered about quality. Because prices were set, there was no interest in monetary policy. Because virtually all inputs and outputs were allocated by the government, there were no concerns about taxes, expenditures, and fiscal deficits. Because external trade was mostly prohibited, there were no worries about trade deficits or tariff revenue. Because every important decision was made in Moscow, government officials in the republics were unconcerned with policymaking. And the public was cynical about the behavior of government officials. Because the republics resented Moscow, the local government officials and state enterprise managers were more intent on limitation of exports to other republics than on fulfillment of Moscow's five-year plans.

These attitudes make PILLS alone inadequate for reform in the former Soviet Union, because, as Fischer (1999) has noted, successful transition requires a broad consensus supporting implementation of reforms. These attitudes can be changed through education, but they also make educational efforts difficult. Reformers have been slow to appreciate the role of education in transitional economies, but broad-based efforts have been organized with increased frequency in recent years. Visiting professors in universities, Muskie fellowships for students, and exchange programs between Western and Eastern institutions have been funded for many years. Advising government officials also involves educational efforts in seminars and tutorials. The new emphasis is on public education through the media: training for journalists, coordinated press conferences and interviews, publication of reports and information (GEPLAC 1998), call-in radio programs, and advertising on television. I provide some illustrations of these educational efforts and conclude with a discussion of the necessary conditions for their effectiveness. The illustrations are presented in the context of some hard lessons taught by recent economic events in Georgia.

\section{EDUCATIONAL EFFORTS}

\section{Lesson 1: Open Economies Are Subject to External Shocks}

After independence, Georgia was cut off from rubles previously supplied by the Russian central bank. In 1993, the government of Georgia ignored warnings from the World Bank and International Monetary Fund (IMF) (International Monetary Fund 1995-98) and began printing currency coupons so fast that prices rose by 7,488 percent in 1993 and by another 6,474 percent in 1994 . After the introduction of a new currency, the lari, in 1997, however, responsible monetary policy eventually eliminated inflation and preserved a stable dollar/lari exchange rate of 0.75 in early 1998 .

Public confidence in the lari was shattered by the Russian financial crisis of 
August 1998. The lari plummeted to $\$ 0.50$ during the first weekend in September, and Georgian newspapers were soon full of stories variously blaming the devaluation on Georgia's dependence on trade with Russia, on the incompetence of Georgian government officials, on unscrupulous foreign exchange retailers, and on manipulation by a banking oligopoly. The Georgian media reflected Soviet attitudes against international trade, against pro-market reformers in government, and against exploitation by financial capitalists.

The National Bank of Georgia (NBG) quickly raised interest rates on interbank credit (the equivalent of our federal funds rate) from 22 percent to 38 percent, intervened in the small foreign exchange market by selling $\$ 15$ million, and announced its intentions to stabilize the exchange rate on television. The lari rose back to $\$ 0.74$ within days, but media coverage of this episode demonstrated the need for more widespread and reliable economic education in Georgia.

The Institutional Reform and the Informal Sector (IRIS) center in Georgia responded with a report examining the economic links between Russia and Georgia (MacPhee 1998a). This report pointed out that Russia accounted for only one-fourth of Georgian exports and that these amounted to only 1 percent of Georgia's gross domestic product (GDP), hardly a vehicle to wreak havoc on the Georgian economy. Georgian imports from Russia were mainly natural gas, electricity, grains, and machinery, items with price elasticities low enough to lower Georgia's import spending in the aftermath of the ruble devaluation. The main difficulty created by the Russian crisis was one that had not been mentioned in the press. At least 200,000 Georgians (one-tenth of those employed) earned income in other parts of the former Soviet Union and made remittances home of income equivalent to 5 percent of Georgia's GDP. The Russian recession would lower those remittances. The decline in demand for the lari, therefore, could be explained by expectations of recession in Georgia rather than by evil doings in the foreign exchange markets.

Nevertheless, the NBG used the crisis as an excuse to shut down 343 of the 465 currency exchange booths that operated in Tbilisi, the capital city that houses almost one-third of the Georgian population. The NBG's move would obviously increase the market power of the remaining booths, which were associated with a few dominant banks. This anti-competitive action, however, was opposed by donor countries and international financial organizations and most of the exchange booths were allowed to re-open. Lobbyists continued to press the government for stricter licensing regulations, requiring bullet proof glass, and so forth, that would drive up the costs of operating small booths and thus drive them out of business.

\section{Lesson 2: Automatic Adjustment Mechanisms Work}

Between its introduction in 1995 and September 1998, the lari had only depreciated 9 percent against the dollar, but this was a result of the IMF's willingness to finance relatively small balance of payments deficits. The NBG had spent $\$ 172$ million defending the lari in 1997, but it had not had to intervene at all in 1998 until the September 1998 crisis. By the end of October 1998, the lari fell 
briefly to $\$ 0.67$, the NBG had only $\$ 100$ million left in reserves, and the IMF was threatening to cut off the stabilization funds because the Georgian government had not collected as much tax revenue as it had agreed to do. This situation provoked wild commentary from government officials and from the media that the lari would go into free fall, and the Georgian economy would collapse. Again, the old Soviet ignorance of equilibrating mechanisms in markets was manifest.

The IRIS center in Tbilisi responded with another report that examined the various components of Georgia's international payments and calculated that the balance of payments deficit was doubling in size (MacPhee 1998b). A simple elasticities approach was used to estimate that the dollar value of the lari would fall 40 percent if no stabilization funds were received from external sources. This would be a substantial devaluation, but the report noted that it was not out of line with the recent experience of other transitional economies, and 40 percent was hardly a free fall. The report did not eliminate sensationalism in the media, but the lari did fall about 40 percent, and since then, it has fluctuated around that low level.

\section{Lesson 3: Instability Hinders Growth}

The report on the devaluation of the lari also explained the effects of the devaluation on inflation, on the burden of Georgia's large foreign debt, and, perhaps most important, on Georgia's fledgling financial sector. In the absence of stock and bond markets, banks were the main source of funding for local business investment. After independence, many defunct state enterprises formed bank subsidiaries, and as many as 229 banks in 1995 existed with less combined capital than one mid-sized American bank. Most of these so-called banks had made loans to insiders who promptly fled with the money, so their assets were often worthless. Moreover, the government had frozen deposits during the hyperinflation of 1994 , certainly not a policy to inspire confidence in potential depositors. Consequently, Georgians kept their monetary wealth in dollars hidden under floorboards, and the banks were largely unable to perform their role of financial intermediation. Bankruptcy and consolidation, encouraged by NBG enforcement of minimum capital requirements and other regulations, reduced the number of banks to 47 by 1998 . Only 22 were considered to be viable and they accounted for almost all the deposits and current lending in Georgia.

The concentration in banking made this sector a natural target for the media and the politicians who decried the low interest rates on deposits (averaging about 14 percent during the first half of 1998), the high interest rates on loans (about 37 percent), and the supposed manipulation of the exchange rates. The devaluation report (MacPhee 1998b) attempted to explain that devaluation actually weakened the banks even more. They were required to hold lari reserves that lost relative value and nervous depositors were making withdrawals. Thus, the abysmally low level of bank lending would fall even lower in an economy that desperately needed more investment.

Risk and inflationary expectations were keeping loan interest rates high and also explained the large spread between deposit and loan rates. The links among the exchange rate, inflationary expectations, and the government's failure to col- 
lect taxes also needed emphasis. In the absence of a bond market and IMF funds, the NBG would be under pressure to monetize the deficit, actions that the public remembered as leading to the hyperinflation of 1994. Inflationary expectations increased the demand for dollars and kept downward pressure on the value of the lari.

These principles of economics were presented to about 40 journalists who attended a three-day workshop sponsored by the World Bank in December, 1998 (MacPhee 1998c). The workshop also covered trade liberalization and the implications of WTO accession for Georgia, privatization in the energy sector, private lending activities of the International Finance Corporation and of subsidized Western banks, as well as sessions devoted to journalism issues.

The discussion of media issues turned out to be revealing as conflicts surfaced between the new private, and mostly young, journalists and the old state-run broadcasters and publishers. After the middle-aged producer of a state radio news series described some of her public information programs on reforms, she was derided by the youths. The young journalists criticized her hypocrisy as a former communist, the tedium of her program (which the youths claimed had low ratings), and her biased reporting on reforms, reforms that the cynical youths regarded as ineffectual. This criticism of the slow reforms presented an opportunity for discussion of the economic concepts of long-run growth and short-run instability with emphasis on the centuries it took for the market system in Western Europe to develop. Nevertheless, the seminar did not succeed in dispelling the cynicism of the young journalists.

\section{Lesson 4: Deficit Monetization Leads to Currency Depreciation}

The need for journalists to learn about the harmful effects of fiscal deficits was evident. The World Bank sponsored a second three-day workshop, the European Union sponsored a semester-long course in Tbilisi; the Academy for Educational Development with USAID funds sent eight journalists to California State University at Chico for courses including macroeconomics and microeconomics, and the USAID-funded Barents Group Fiscal Reform Project held weekly seminars during spring 1999. Economic advisors also offered a three-week course on macroeconomics to 35 future government officials in the masters program of the new Georgia Institute of Public Administration, a program funded by the United States.

Reporting on the importance of fiscal reform improved and the media expressed more skepticism toward government officials who blamed their failure to collect more tax revenue on the bad weather and the Russian crisis. A public opinion survey indicated that the public was getting the message. About 92 percent believed that corruption was an impediment to collecting taxes and 82 percent said that they would pay their taxes if everyone else did. Seventy-two percent felt that tax rates were too high, however, and most thought that revenues were going to pensioners and the police rather than to their high priorities: education and health care. Despite the increased public awareness of the causes and consequences of deficits, the rate of tax collections actually fell in late 1998.

On December 4, 1998, the NBG gave up its defense of the lari and, as noted 
previously, its value fell about 40 percent. This unleashed a torrent of wild statements in the media, reflecting either economic ignorance or demagoguery. The press reported immediate price increases of 60 percent, stirring up fears of a resumption of runaway inflation. The volatility of the lari's exchange value, which bobbed up and down between $\$ 0.47$ and $\$ 0.63$ a dozen times in the first two months of floating, also contributed to uncertainty. Of course, the press was full of stories blaming the ups and downs on conspiracies among banks, exchange dealers, and corrupt government officials. A jump in kerosene prices was attributed to a cartel controlled by Nugzar Shevardnadze, the president's nephew, instead of the onset of cold weather and a decrease in electricity supply.

The time was right for more exercises in public education. In December 1998, U.S. advisors went on a radio call-in show, and in February 1999, the IRIS center issued another report explaining the reasons for volatility and the links between inflation, devaluation, and the fiscal deficit (MacPhee 1999a). One did not need conspiracies to explain volatility. The exchange market for the lari was very thin, and it was driven by expectations that changed with each bit of bad or good news from Russia or the IMF. People held more dollars than lari, but they would change into lari for transactions such as holiday shopping, thereby causing temporary appreciation. Monetary policy had tightened after the September crisis, but government spending financed by the National Bank led to a 22 percent increase in the lari money supply in December 1998. The report concluded that "Nothing would bolster the lari like a big increase in tax collections."

Both the February report and a subsequent IRIS study (MacPhee 1999b) disputed the runaway inflation claims. The IRIS staff carried out an independent survey of the most important items in the Georgian consumer price index (CPI) and found that the CPI was fairly accurate. In the first two months after the devaluation, the CPI rose only 15 percent. The reports of 60 percent inflation were bogus.

\section{Lesson 5: Taxes Plus Collections Equals Revenue}

Shortly after issuance of the February report, the United States announced a narrower emphasis for technical assistance efforts with concentration on just a few areas, the most important one perhaps being tax collections. The American ambassador visited with the Georgian president to gain his assurance of cooperation, and the fiscal reform project began a much more aggressive program. Most of the fiscal reform activities involved retraining tax inspectors, reorganizing the tax department, and overseeing the implementation of new policies such as excise tax stamps.

The IMF had long insisted on increases in tax collections. Higher revenue was favored by USAID, the Georgian parliament, and the Georgian president. The Ministry of Finance in prior years had issued budgets based on optimistic projections of tax revenue, in part to set high goals for the independent tax department. But there had never been any systematic effort to estimate the size of the tax bases that should be the foundation of serious projections. The responsible government officials needed to be educated on the methods that economists would use to estimate the size of the tax bases. 
Advisors from the U.S. Treasury, the IMF, and the USAID-funded Barents Group Fiscal Reform Project met with officials of the State Department of Statistics, the Macroeconomic Forecasting Department of the Ministry of Finance, the Parliament Budget Office, members of the Parliament Budget Committee, and the Ministry of Economy. The main problem facing estimation of potential tax revenue turned out to be the lack of reliable statistics on the economy. The Department of Statistics and most ministries were full of Soviet-era apparatchiks even though the leaders were young, sometimes with American training in economics. The apparatchiks were used to sitting back and receiving often-erroneous and usually unaudited reports from state enterprises, which they would then aggregate in order to issue their quarterly statistical review for the republic.

The Statistics Department staff were not doing what one normally thinks of as economic statistics. They had little awareness of sampling techniques or statistical inference. When advisors demonstrated to them how the travel component of the current account could be estimated with a short telephone survey of 20 active hotels in Tbilisi (MacPhee 1998d), the staff responded with a 10-page questionnaire for 1,000 (mostly defunct) hotels in Georgia and a proposal for a law requiring the hotels to file the report monthly. At this point, the advisors gave them a short lesson on cost-benefit analysis that unfortunately did not halt the bureaucratic momentum behind the comprehensive questionnaire.

Despite years of intermittent training by IMF and European advisors, the national income accounts and trade statistics were still unreliable. The World Bank, however, had installed some former statistics professors in the Department of Statistics in order to do a fairly reliable household survey. Thus, some reasonably accurate information on consumption could be pieced together with some of the more reliable production data using the international trade identity: consumption $=$ production - exports + imports. Fiscal advisors demonstrated to the Georgians the ways in which they could estimate the tax bases for customs duties and excises on cigarettes, gasoline, and alcohol, as well as the value-added tax (MacPhee 1999c-h). Eventually, they agreed to form an interagency working group that would employ these methods on a regular basis to introduce more realism into the Georgian budget. Most of the estimates were astounding. The foregone revenue from cigarettes alone would have covered 40 percent of the total government budget deficit. The tax collection rate on petroleum products was only 44 percent, and collection of VAT was only 48 percent of potential.

Fiscal advisors also worked with the Ministries of Finance and Economy on the subject of forecasting revenues (MacPhee 1999i,j). Here the previous educational efforts of a series of short-term advisors from the U.S. Treasury, the IMF, and the World Bank had gone astray. Forecasting seminars had been offered to the staff, and computer hardware and software had been provided. Afterward, the staff spent their time constructing models using data from unreliable time series, none longer than four years. Then they would issue their wildly over-optimistic forecasts without disclosing anything about the model.

With sensitivity to the emotional investment some of the Georgian staff had in 
their forecasting work, the fiscal advisors took a very low-key approach. U.S.trained Georgian advisors worked with the forecasting staff to document their model, to review the unreliable data and, in the process, to suggest improvements. The advisors also explained the importance of careful interpretation of forecasts in light of their inevitable inaccuracies. The staff of the Ministry of Finance seemed to react favorably to this approach, but it will not be until future budgets are formulated that we will be able to assess the outcome.

\section{Lesson 6: Economic Principles Appear on Television}

To encourage the compliance of taxpayers and the re-election of reformers, the USAID funded an extensive public education campaign with a series of television messages in the summer of 1999. The television messages were scripted and produced by Georgians and, like commercial messages, they were short and superficial. Nevertheless, each of the messages reflected a principle of economics, although not all were principles that are commonly emphasize in American classrooms.

Here are the lessons that the television messages attempted to communicate: People need to make choices. People need to be adaptable because economic growth requires change, a point illustrated visually by a steam locomotive being transformed into a bullet train and by a VW Beetle being transformed into a racecar. Growth will benefit future generations, a message reinforced by a scene of the Pilgrim ships giving way to the lunar landing. The American market system is worthy of emulation, demonstrated by scenes of the Manhattan skyline. People need to cooperate and work together in the new system in order to accomplish their goals, illustrated by armies of workers building the pyramids in Egypt and by two cartoon spacemen working cooperatively on an alien planet. Reform is a long process but it has a lot of momentum and there is no going backward, symbolized once again by the locomotive transformed into bullet train. World markets are competitive and competitors have to move fast, again demonstrated by the transformed VW racing around a speedway. The main purpose of taxation is to finance public goods, a message backed up with pictures of Georgia's natural scenery and wildlife, historical monuments, roadways, and school children. Tax evasion hurts all of us by denying public goods to ourselves. The obvious free rider problem was ignored until the last message about penalties for failure to pay taxes, illustrated by a scene of tax inspectors confiscating cases of unstamped cigarettes and alcohol.

These were basic messages, some might even say platitudes, but public opinion surveys had revealed widespread public ignorance about the reform process. The television messages addressed the fundamental ideas that markets are a form of cooperation and that government has a legitimate role in a market economy. Whether the messages accomplished their goal, however, is an open question. The pro-reform coalition in parliament managed to maintain its majority in elections at the end of October 1999, and excise tax collections rose in the late summer and early fall of 1999. However, tax collections again fell in late 1999 and the IMF again began withholding stabilization funds. 


\section{CONCLUSIONS}

Although this article is confined to broad-based educational efforts in only one of the 15 republics of the former Soviet Union, a similar need for economic education exists in most other transition economies. After a decade of reform, there is still widespread belief in the outmoded Soviet ideas of isolationism, government control, capitalistic exploitation and instability. These ideas impede the process of reform by providing a rationale for government policies that are inefficient, fiscally and monetarily irresponsible, anticompetitive, and inflationary. These ideas also foster corruption among poorly paid government officials and cynicism among the citizens.

The technical assistance community has gradually become aware of the barriers to reform erected by the old ways of thinking. This awareness has motivated the recent emphasis on education through advising government officials, training journalists, and providing accurate information to the general public. These educational efforts have faced their own share of difficulties: mistakes in translation, lack of continuity, overly sophisticated concepts, and poor coordination among the various agencies providing technical assistance.

Economic educators in transition economies need to place more emphasis on the very basic ideas of scarcity, choices, short run, long run, and tradeoffs. They need to stress the importance of accurate measurement of economic variables. They need to give repeated explanations of the sources of change and the equilibrating mechanisms in market economies. They need to clarify the roles of competition, property rights, and stable government policies. Finally, they need to remind the local citizens as well as the technical assistance community that the reform process is a long one. The evolution of the market system in Western Europe did not take place overnight, and one should not have unrealistic expectations that the present economic reforms will take less than a generation.

\section{REFERENCES}

Fischer, S. April 23, 1999. The financial crisis in emerging markets: Lessons for Eastern Europe and Asia. Speech to the East West Institute. New York.

GEPLAC (Georgian-European Policy and Legal Advice Centre). 1998. Georgian economic trends (3). Tbilisi: TACIS (Technical Assistance for the Commonwealth of Independent States from the European Union).

International Monetary Fund. 1995-98. Georgia: Recent economic developments. IMF Staff Country Reports No. 95/1 12 (November), 96/116 (November), $97 / 36$ (May), and June 12, 1998. Washington, D.C.

MacPhee, C. R. 1998a. Georgia and the fall of the ruble. Tbilisi: IRIS Caucasus Center. September 7.

- 1998b. Devaluation of the lari and its effects. Tbilisi: IRIS Caucasus Center. October.

.1998c. Credits for travel in the Georgian balance of payments. Tbilisi: IRIS Caucasus Center. December 1. ber 5 .

. 1998d. $Q \& A$ on the lari and the Georgian economy. Tbilisi: IRIS Caucasus Center. Decem-

. 1999a. Cigarettes and deficits in Georgia. Tbilisi: IRIS Caucasus Center. February 4.

February 17.

1999b. The lari roller-coaster and the Georgian economy. Tbilisi: IRIS Caucasus Center.

ter. March 5.

1999d. Where have all the flours gone? Tbilisi: IRIS Caucasus Center. March 15.

. 1999e. The consistency of Georgian statistics on ethyl spirits and derivative beverages. Tbil- 
isi: IRIS Caucasus Center. March 19.

1999f. General principles for the macroeconomic component of the basic directions document for the budget in 2000. Tbilisi: Barents Group Fiscal Reform Project. May 10.

$1999 \mathrm{~g}$. Basic directions document for the 2000 budget: Macroeconomic environment. Tbilisi: Barents Group Fiscal Reform Project. May 19.

1999h. Potential government revenue from gasoline in Georgia. Tbilisi: Barents Group Fiscal Reform Project. June 9.

1999i. Forecasts of Georgian value-added tax revenue. Tbilisi: Barents Group Fiscal Reform Project. June 10.

1999j. Potential Georgian government revenue from petroleum products. Tbilisi: Barents Group Fiscal Reform Project. June 23.

Stiglitz, J. 1999. Whither reform? Ten years of the transition. Annual World Bank Conference on Development Economics. Washington, D.C.: World Bank.

\section{Virtual Economics 2.0 The acclaimed interactive CD-ROM resource for economic educators}

$\star$ Indispensable comprehensive teacher training tool for $\mathrm{K}-12$ cross-curricular instruction

$\star$ Inviting, accessible, fun to use. 3 -dimensional interactive gallery provides complete introduction to basic economic concepts

$\star$ Appropriate for designing teacher training seminars, pre-college curricula, and introductory college-level economics courses

$\star$ Puts the new Voluntary National Content Standards in Economics to work

$\star 30,000$ page printable library includes professional references, data sets, lesson plans, and context-based student activities and worksheets

For single station (\$74.95) or network usage (\$149.95) $P C$ and Mac compatible.

Available from the National Council on ECONOMic EduCation

For further information or to order, call 1-800-338-1192, ext. 763

National Council

on Economic Education 